\title{
Effect of Deposit Mobilization and Credit Financing of Commercial Banks on Capital Formation in Nigeria
}

\author{
Byyiyet Josiah Jacob \\ Department of Banking and Finance \\ Ahmadu Bello University, Nigeria \\ Email: Biyetybjacob@gmail.com \\ Yusha'u Ishaya \\ Department of Business Administration \\ Federal University, Gashua \\ Email: Ishayakhma09@gmail.com \\ Idachaba Odekina Innocent \\ Department of Banking and Finance \\ Ahmadu Bello University, Nigeria \\ Email: Innocent4grace@gmail.com
}

\begin{abstract}
The low level of Capital formation in Nigeria has been blamed on the low level of savings occasioned by the low income level and high level of consumption which reduce the ability of banks to create money through intermediation. This study investigates the effect of deposit mobilization and credit financing of commercial banks on capital formation in Nigeria. Gross fixed capital formation was used as proxy for dependent variable, while credit to private sectors, lending rate and Total deposit liabilities were used as proxies of independent variables. The study employed time series quarterly data from QI I980 to Q4 20I5, which constitutes 48 observations. Multiple regression techniques were used to analyze the data. The study found that (LRN and TDL) have positive impact on GFCF of Nigeria while credit to private sector has an inverse relationship with GDP. In view of this finding, the study recommended that Nigeria commercial banks should re-direct their intermediation activities effectively
\end{abstract}

Keywords: Capital formation, Commercial banks, Deposit Mobilization, Finance

JEL Classification: C22, C87, G2, G2I, G29

\section{I.Introduction}

Deposit mobilization is one of the important functions of banking all over the world. It is an important source of the Bank's labor fund and has been proven by scholars such as Jhingan (200I), Uremadu (2002), Bakare (201I), Orji (2012) among others as an indispensable factor for increasing the sources of banks to operate effectively. The mobilization of deposits plays an important role in providing satisfactory service to various sectors of the economy. However, the ability of banks to generate growth and economic development depends on the health, solidity and stability of the banking system itself (Alex, 20I2). The relationship between the mobilization of bank deposits, the financing of bank credit and the formation of capital is through the activities of the banking industry such as mobilization of deposits and creation of credits. However, it has been argued in the public domain that banks have not been performing effectively to improve capital formation to guarantee a sound financial system (Venkati, 2016).

Capital formation or real investment is an important element of economic development and growth. Large-scale capital formation is very beneficial. Existing share capital may need to be replaced by normal depreciation, plants may need to expand the economy in order to benefit from economies of scale and be competent in increasing market demand. The intensification of competition would dictate investment in the latest technology, may require plant assets and stocks if the supply of raw material or market for the end product indicates a high degree of seasonality. In all cases, real investment can only be realized if sufficient funds are available. While there is need to identify various sources of fund mobilization, borrowing from abroad can have 
negative effects on the balance of payments as it depends on how the loan might be used and also the level of exchange rate risk exposure. Therefore, domestic savings are necessary for economic growth because they provide the domestic resources needed to meet the investment efforts of a country.

The rate of growth in Nigeria economy cannot be over emphasized without looking at the contribution of capital formation to Nigeria's economic growth. It means that capital formation has been recognized as an important driven factor that determines the growth of Nigerian Economy. No country has enjoyed or achieved sustainable investment in capital formation. In a bid to attain economic growth around the world, emphasis has been placed on increased capital formation. It is good to understand the determinants of the capital formation so as to design numbers of policy interventions towards achieving economic growth. Capital formation refers to the proportion of present income saved and invested in order to augment future output and income. It usually results from acquisition of new factory along with machinery, equipment and all productive capital goods. This study is necessary due to the consistent decline in private savings in Nigeria, finance investment required for economic growth, the economic need to generate sufficient savings.

One of the strategies for the mobilization of deposits is "Target deposit". The mobilization of deposits plays a fundamental role in the financing of the bank, since a predominant part of the commercial bank's assets is usually financed by customer deposits (Bologna, 201 I). The main expense of any commercial bank is the interest expense and, therefore, for a commercial bank to be profitable, it must be able to collect deposits at reasonable rates to lend to the clients. Therefore, this implies that a bank that can generate more deposits at low cost will be able to offer more loans in a competitive manner and, therefore, will generate more profits if all other factors remain constant. Commercial banks, as well as the sector in general, depend on the deposit of the client to advance their customers. According to Sharma (2009), bank credit and bank deposits are closely related and represent, in general terms, two sides of the same coin.

This research work therefore examines effect of deposit mobilization and credit financing of commercial banks on capital formation in Nigeria.

\section{Statement of the Problem}

The low level of capital formation in Nigeria has been blamed on the low level of savings occasioned by the low income level and high level of consumption which have reduced the ability of banks to create money through the intermediation and contribute to the lack of investible funds in the country. Firms suffer severely for lack of funds to expand their activities and run their daily operations. Banks cannot mobilize adequate deposits from the public because the banking public sector lacks the funds to invest in securities of financial institutions. This discourages financial innovations and increases financial shallowness.

The consequences of these are many as firms do not have adequate funds to finance their operations which further reduce the volume of deposits mobilized and the credit creation in the financial sector. The lack of investible fund renders firms illiquid and contributes to their inability to acquire modern technology and fund their expansion. Banks, the world over, thrive on their ability to generate income through their lending activities. Since commercial banks depend on depositor's money as a source of funds, it means that there are some relationships between the ability of the banks to mobilize deposits and the amount of credit granted to the customers. For the purpose of achieving self-sufficiency there is the need to improve ways of mobilizing domestic deposits. Records indicate that large chunk of deposits are lying idle under pillows and in bamboos in the rural areas being left out of the banking Stream (Thangam \& Ganapathy, 2017). Therefore commercial banks should increase ways to approach and mobilize the huge deposits lying in the unbanked people to maximize and maintain their Portfolios. The banking system is the growth of the economy financial intermediation function. With this function, the bank facilitates the creation of capital, to improve the production capacity of the economy. Financing of bank deposits, credit financing and capital formation and the banking industry activities, such as deposits mobilization and the creation of loans in the economy has not been given much attention.

To a great extent, the positive relationship between deposit mobilization, credit financing and capital formation has long been affirmed in previous empirical studies but in country-specific studies like Ethopia and Rwanda etc, the structural variations that is recurring change caused by factors such as seasonal pattern or long time trends among countries may not have been adequately accounted for. Success in capital accumulation and formation for economic growth varies among nations and largely dependent on deposit liabilities of commercial banks, credit financing and a host of other factors but the omission of these core variables that accounts for country-specific differences in the specification of the growth models possibly could have introduced some bias and inconclusiveness in the result of previous studies. In a bid to fill this gap in literature, this study incorporates these variables in the investigation of long-run relationship between deposit mobilization and capital formation in Nigeria

\section{Research Questions}

Based on the above problems, the following research questions were outlined:

- Does credit financing to private sector influence gross fixed capital formation in Nigeria? 
- Does lending rate influence gross fixed capital formation in Nigeria?

- Does a total deposit liabilities bank influence gross fixed capital formation in Nigeria?

\section{Objectives of the Study}

The broad objective of this study is to examine the impact of deposit mobilization and credit financing of deposit money banks on the capital formation of Nigeria. Specifically however, the study seeks to

- To investigate the effect of bank credit to private sector on gross fixed capital formation in Nigeria

- To determine the effect of lending rate on the gross fixed capital formation in Nigeria

- Determine the effect of total deposit liabilities on the gross fixed capital formation in Nigeria.

\section{Statement of Hypothesis}

In line with the research objectives, the following hypothesis were tested in this study,

- Hor There is no significant relationship of credit financing to private sector on gross fixed capital formation in Nigeria.

- $\mathrm{H}_{\mathrm{o} 2}$ There is no significant relationship of lending rate and gross fixed capital formation in Nigeria.

- $\mathrm{H}_{\mathrm{o}}$ There is no significant relationship of total deposit liabilities on gross fixed capital formation in Nigeria.

\section{Literature Review}

\section{I Concept of capital formation}

Capital formation is a term used to describe the net capital accumulation during an accounting period for a particular country, and the term refers to additions of capital stock, such as equipment, tools, transportation assets Bakare (20I I) defines capital formation as that which relates to the share of current saved and invested income in order to increase future output and income. It is usually the result of acquiring a new factory with machines, equipment, and all production capital. Capital formation is equivalent to an increase in physical capital stock of a nation with investment in social and economic infrastructure.

Economic theories have shown that capital formation plays a crucial role in the models of economics growth (Beddies I999 and Gbura 1997).

Capital formation refers to the process of amassing or stocking of assets of value, the increase in wealth or the creation of further wealth. The Central Bank of Nigeria (2007), defines capital formation as the total change in the value of fixed assets in the economy in addition to fixed assets either for replacing or adding to the stock, it refers to the increase in the fixed capital stocks of the capital formed.

Capital formation means increasing the stock of real capital in a country. It involves making of more capital goods such as machines, tools, factories, transport equipment, materials, electricity etc which are all used for future production of goods.

\subsection{Concept of Deposit Mobilization}

Deposit mobilization is an integral part of banking activity. Mobilization of savings through intensive deposit collection has been regarded as the major task of banking all over the world. Deposit mobilization is the collection of cash or funds by a financial institution from the public through its current, savings, fixed recurring accounts and other specialized schemes (Digaria, H.A.20II). Mohan (2012) pointed out that banks plan their deposit mobilization strategy depending on the country's investment growth through the growth of the branch, using technology technologies, continuous training of staff boosting the deposit, increasing the organization's confidence, or the current branch, expanding bank deposit products, utilizing high media coverage, branch expansion, home-based learning about benefits to deliver, to provide door to door service and so on.

Deposit mobilization is defined by Elser et al (1999) as the process of encouraging customers to deposit cash with the bank or luring new clients to come and open accounts with the bank. From an institutional perspective, the primary motive for mobilizing savings lies in lower cost of capital compared to other sources of funds.

According to Kutanet al (2010) banks serve as intermediaries accepting commercial and individual deposits (savings) and transferring them in the form of loans to investments. Since the adoption of the multiple currencies in 2009 local banks went on a massive deposit mobilization drive by offering a range of products and services that are tailored to their particular clientele which saw them pool substantial amounts from the depositors. Deposit Mobilization is the bedrock of the present future growth of banks.

\subsection{Concept of credit financing}

Credit is an extension of money from the lender to the borrower. It is commitment to pay another for the borrowed money or the goods and services received. The loan cannot be divorced from the banking sector because banks serve as a means of receiving cash in the form of deposits surplus of units in the economy and transferred to the deficit units that need the funds for productive purposes. Banks are therefore debtors of depositors of funds and creditors to borrowers of funds (Ajayi, 2007). The bank credit is the amount of money (fund) available for a company or an individual from banking system, credit financing deals 
with the aggregate amount of funds that financial institutions are willing to provide an individual or organization. The bank credit of a company or an individual depends on both the debtor's ability to pay and the total amount of credit available in the banking system. The loan is the main element on the active side of the consolidated financial sector balance sheet; measures the size of the assets of the financial sector.

\subsection{Concept of lending Rate}

The interest rate on the loan is another securities commission, which usually meets the short and medium term financing needs of the private sector. This rate differs generally from credit worthiness to borrowers and financial means According to Nzottan (2002), factors affecting Nigeria's lending are the bank's point of contact, risk and profitability of different types of bank credit, financial situation, monetary policy, talent and exposure banks' staff, credit standards for the service sector and the nature of the bank's source. Nzottan said that bank loan refer to a bank's activity that provides the debtor with the advance after taking risk and profitability into account must comply with such a lending decision.

\subsection{Review of related studies}

In order to empirically investigate deposit mobilization and credit financing of commercial banks on the capital formation in Nigeria, the following studies were reviewed.

John, Isaac and Nathaniel (2017) examine credit risk, deposit mobilization and profitability of Ghanaian banks. Panel regression analysis was adopted for this study, variable include Return on Asset while Non performing loan ratio, deposit mobilization, capital adequacy ratio, total asset of bank, inflation and growth in interest income are the independent variables. The result reveals a significantly positive relationship between credit risk, deposit mobilization, growth in interest income, capital a dequacy ratio and profitability of Ghanaian banks. This study fails to carry out diagnostic test such as normality test, multicollinearity test.

Mamo (2017) conducted an investigation of determinants of deposit mobilization in commercial banks of Ethiopia. Multiple linear regression was adopted for this study, the variables are competitors, interest, branches and loan while dependent variable is Total deposit. The result of the econometric indicates that loan provision, branch expansion and number of customers are found to have significant positive impact to induce deposit mobilization. The study fails to carry out all the necessary residuals test to fulfill regression assumption before running the regression.

Ogar and Oka (2017) examine the impact of financial deepening on capital formation in Nigeria. Ordinary least square model, multiple regression Analytical technique and Desk survey method were adopted for this study. Variable include Gross fixed capital formation while broad money supply to GDP, gross domestic investment to GDP, credit to private sector to GDP and interest rate spread are independent variables. They found out that financial deepening has a positive impact on capital formation. However, the study failed to capture total deposit liability and lending rate and this could affect the validity of the study.

Oka and Adesola (2017) Determine Deposit money banking financing and its effect on real sector output in Nigeria: Evidence from trade and Agricultural sectors. Vector error correction mechanism and Augmented Dickey fuller was used for the study. Variables includes Deposit mobilization bank, private sector credit, Banks holding of treasury bills and interest rate spread while Agricultural sector output and Trade sector output are dependent variables. The study found that the deposit money banks financing has a long run significant effect on trade sector output but an insignificant long run effect on agricultural sector output in Nigeria. However, the study failed to document various diagnostic tests such as normality test model specification test, serial auto correlation test among others.

Henry, Lucky and Anyamaobi (2016) examine Banking sector development and capital formation in Nigeria: A multivariate Analysis. Capital formation to Gross domestic product as dependent variable while Bank credit to GDP, Bank investment to GDP, Bank deposit to GDP, Bank total assets to GDP and prime lending rate are independent variables. The study employed ordinary least square, augmented dickey fuller unit test, Granger causality test and Vector error correction model as method for this study. The study revealed a static regression result that all the independent variables have positive relationship with the dependent variable except prime lending rate which confirms the expected results in the study. The study conclude from the findings that the banking sector development have significant effects on Nigerian Capital.

Venkati (2016) examined the impact of banks deposit mobilization and credit financing on capital formation in Ethiopia. Ordinary least Square method was adopted for this study, Gross fixed capital formation was used as dependent variable while independent variables includes Bank credit, bank deposit and bank investment. The study found that bank deposit, bank credit and national saving have a great role on capital formation in Ethiopia. However, but the finding of the study can not be extrapolate into the Nigeria context due to time and difference in peculiar factors.

Pascal, Chibueze and Callistus (2016) examined bank credit and capital formation in Nigeria and adopted Error correlation Model, Co-integration test and multiple regression method. They use Gross fixed capital formation as dependent variable while bank credit, interest rate, exchange rate, government expenditure and monetary supply as independent variables. 
This study found a positive but no significant impact of bank credit on capital formation in Nigeria. The lack of significance of bank credit may be attributed to the bottlenecks or stringent rules surrounding credit allocation by bank which frustrate the efforts of monetary and federal authorities in Nigeria to let funding get to where they are most urgently needed. However, the study fails to carry out all the necessary residuals test to fulfill regression assumption before running the regression.

Chukwunonso, Ogonna, Clement and Anthony (2016) conducted a study on Analysis of savings and private capital formation in Nigeria. The methods for this study are Ordinary least square method, Co-integration and Error correction mechanism. The variables include inflation rate, savings, prime lending rate of deposit money banks, real gross domestic product, foreign direct investment and capital expenditure while dependent variable is Gross fixed private capital formation. The result shows that savings play a major role in private capital formation both in Nigeria given that savings exert a negative and significant effect on private capital formation in Nigeria, an improvement can be done through working towards increased per capita income which will increase the disposable income which will increase the disposable income of Nigerian citizens and improve savings culture.

Shuaib and Dania (2015) conducted a study on capital formation: impact on the economic development of Nigeria. This study adopted Harrod-domar model, the variables includes Gross capital formation, total government expenditure, interest rate, inflation rate, total saving rate, investment and external domestic rate while Gross domestic product as dependent variables. The study found out that capital formation and its components (determinants) have significant relationship with the economic development in Nigeria.

Tuyishime, Memeba and Mbera (2015) examined the effects of deposit mobilization on the bank financial performance in commercial banks in Rwanda. A case study of Equity bank Rwanda limited. Financial performance as dependent variable while independent variables include marketing strategies, change of deposits interest rate and Banking technology. This study adopted Pearson and spearman's correlation. The findings also indicated that a positive change in deposits interest rate affects the level of deposits received and later on the profitability of the bank. From the findings of this study, it can be concluded that the deposits mobilization positively affects the financial performance of commercial bank in Rwanda. The study failed to document the various diagnostic tests such as normality test, model specification, serial auto correlation test among other.

\section{Theoretical Framework}

The underpinning theory guiding this study is supply led finance theory. This is explained as follows:

\section{I The Supply Led Finance Theory}

This theory was first developed by Patrick (1966), who "stressed that finance is one of the leading aspects of economic development". Supply led finance theory is growth inducing or growth induced, which means finance is the most significant factor for promoting economic development. The provision of funds through financial institutions to support the creation, transformation, expansion of industries and developmental projects is an element of the supplied theory. Furthermore, the supply-led finance theory can simply be described as the establishment of financial institutions in some areas before their products and services are effectively demanded.

In 1976, pius Okigbo's financial review committee in Nigeria, with respect to rural banking schemes in 1977 and the introduction of community banking system in 1990 to help encourage savings mobilization and credit expansion were direct reactions to the supply led finance theory. Access to supply leading finance creates enabling financial environment for entrepreneurs to think big (Patrick, 1966).

The rate of growth in Nigeria economy cannot be fully examined without a closer look at the contribution of capital formation to Nigeria's economic. For a country to develop and grow, it must divert part of its resources from current consumption (or save) and invest them in capital formation.

This is the understanding that Capital formation has been recognized as an important factor that determines the growth of Nigerian economy, thus, a high rate of capital formation lead to a high rate of productivity which brings about growth. No country has achieved sustained economic growth without substantial investment in capital formation. Once the financial intermediation plays their role in time of pooling of funds from the surplus to the deficit by making the funds available as form of loan, it help to enhance circulation of funds in the economy that result to capital formation.

\section{Methodology}

The aim of the research is to examine the effect of Deposit Mobilization and Credit Financing of commercial banks on Capital Formation in Nigeria using annual data covering the period from 1980 to 2015. The study employed correlational research design. The choice of this research design is due to time series nature of the data collected from the period 1980-2015. 


\section{I Empirical Model}

The regression technique is an important tool in econometrics. In general, a regression is concerned with examining the linkages between a given variable and one or more other variables. It is an attempt to describe changes in a variable by reference to change in other variables. The regression model is stated as

This regression model can be interpreted whether a set of deposit mobilization and credit financing factors has a linkage with capital formation, where $\mathrm{R}$ is the Capital Formation proxied by GFCF and X's represents the deposit mobilization and credit financing variables used in this study. $\mathrm{X}$ is the intercept of the regression that is, constant term, $\mathrm{B}_{\mathrm{I}}-\mathrm{Bx}$ are the coefficient of variables and $U_{e}$ is the error term.

The model was modified as follows:

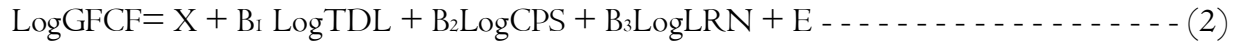

These variables were so chosen because they are majorly the key sectors that could spur Capital formation. As such, their Positive contribution should lead to increase in Gross Fixed Capital Formation

Table I: Operational definition of the Variables

\begin{tabular}{|c|c|c|c|}
\hline Variables & Measurement & Source & Aprior Expectation \\
\hline GFCF & $\begin{array}{l}\text { Gross fixed capital formation refers to the net increase in } \\
\text { physical assets (investment minus deposits). }\end{array}$ & CBN Statistical Bulletin & Positive Sign \\
\hline TDL & $\begin{array}{l}\text { Bank deposits consist of money placed into banking } \\
\text { institutions for safekeeping. These deposits are made to } \\
\text { deposit account such as saving, checking and money market } \\
\text { accounts. }\end{array}$ & CBN Statistical Bulletin & Positive Sign \\
\hline CPS & $\begin{array}{l}\text { Credit to private sector refers to financial resources provided } \\
\text { to the private sector by financial corporations such as loans. }\end{array}$ & CBN Statistical Bulletin & Positive Sign \\
\hline LRN & $\begin{array}{l}\text { Lending rate is the rate of interest charged by a financial } \\
\text { institution for lending money. }\end{array}$ & CBN Statistical Bulletin & Negative Sign \\
\hline \multicolumn{4}{|c|}{ Source: Researcher's Computation, 2019} \\
\hline \multicolumn{4}{|c|}{$\begin{array}{l}\text { 9. Presentation and Discussion of Results } \\
\text { Table 2: Summary results of Stationarity Test }\end{array}$} \\
\hline Variables & Ist Differences ( $\mathrm{p}$ - value & \multicolumn{2}{|c|}{ Integration Order } \\
\hline Log GFCF & Rejected & \multicolumn{2}{|c|}{$\mathrm{I}(\mathrm{I})$} \\
\hline Log TDL & Rejected & \multicolumn{2}{|c|}{$\mathrm{I}(\mathrm{I})$} \\
\hline Log CPS & Rejected & \multicolumn{2}{|c|}{$\mathrm{I}(\mathrm{I})$} \\
\hline Log LRN & Rejected & \multicolumn{2}{|c|}{$\mathrm{I}(\mathrm{I})$} \\
\hline
\end{tabular}

Source: Computation of Result summary from E-view IO Student edition Output

From the result, all the study variables are stationary after differencing once (P-values less than 5\% significant level). This indicates that the variables are all integrated of order $\mathrm{I}(\mathrm{I})$, a necessary and compulsory pre-condition for the use of VECM, at the first difference where the variables are stationary.

\section{I Optimal Lag Selection}

In the adoption of econometries approach such as co-integration test and VECM estimation, the choice of optimal lag is nonnegotiable for a reliable result. Optimal lag selection can be done with the aid of several criteria individually or combined such as Final Prediction Error (FPE), Akaike Information Criterion (AIC), Sehwar 2 Information Criterion (SIC). The AIC is adopted by this study because according to sarah (2008), it yields better results. According to AIC Selection Criterion, the lower the test statistics, the better the model, this study therefore selecting optimum lag of 2 .

\subsection{Co-integration Test}

This is an important analysis that helps to test for long-run stables relationship among the variables of interest in a study, when a linear combination of variables that is of order $\mathrm{I}(\mathrm{I})$ produces a stationary series than the variables may need to be co-integrated (Olokoyo, 20II). 
Table 3: Trace Statistics and Max-Eigen Co-Integration Test Unrestricted Co-integrated Rank Test (Trace)

\begin{tabular}{llllllll}
\hline $\begin{array}{l}\text { Hypothesis } \\
\text { No. CE(s) }\end{array}$ & $\begin{array}{l}\text { Eigen } \\
\text { Value }\end{array}$ & $\begin{array}{l}\text { Trace } \\
\text { Statistics }\end{array}$ & $\begin{array}{l}0.05 \\
\text { Critical } \\
\text { Value }\end{array}$ & Prob. & $\begin{array}{l}\text { Max- Eigen } \\
\text { Statistics }\end{array}$ & $\begin{array}{l}0.05 \\
\text { Critical } \\
\text { Value }\end{array}$ & Prob. \\
\hline None & 0.0643174 & 41.18673 & 29.79707 & 0.0016 & 27.82369 & 21.13162 & 0.0049 \\
\hline At most I & 0.338194 & I3.36303 & I5.4947I & 0.1021 & II.I45I5 & I4.26460 & 0.1471 \\
\hline At most 2 & 0.078860 & 2.217878 & 3.841466 & 0.1364 & 2.217878 & 3.841466 & 0.1364 \\
\hline
\end{tabular}

Source: Output from E-view IO Student Edition

From Table 3 above, both trace and max-Eigen criteria agree on the existence of only one co-integrating equation and that no co-integrating vector exist in the model. Since co-integrating vector and only one long-run exist in the equation, it is therefore expected to run Vector Auto Regression (VAR) to establish the effect of deposit mobilization and credit financing of Commercial banks on Capital formation.

\subsection{Vector Auto regression Estimates}

Table 4: Vector Auto regression Estimates

\begin{tabular}{llll}
\hline Variables & \multicolumn{1}{c}{ Coefficent } & Standard Error & t-statistic \\
\hline $\mathrm{C}$ & 3.720767 & $4.188 \mathrm{I} 5$ & 0.88840 \\
\hline LTDL & 0.750354 & $0.1244 \mathrm{I}$ & 6.03135 \\
\hline LCPS & 0.801233 & 0.1 I055 & 7.24746 \\
\hline LLRN & 0.604230 & 0.14674 & 4.11772 \\
\hline R- Square & 0.662905 & & \\
Adj. R-Square & 0.622453 & & \\
F-Statistics & I6.38 & & \\
\hline & &
\end{tabular}

From the regression results in the table 4 above, the adjusted $\mathrm{R} 2$ is 0.622453 . This shows that independent variables (Log TDL, Log CPS and Log LRN) specified in the model explained only about $62.24 \%$ of the variations in the dependent variables (Log GFCF) over the observed years while the remaining $37.76 \%$ are explained by all other factors that are not included in our model estimates.

The coefficient of Total deposit liabilities (LTDL) is 0.750354 . This shows that total deposit liabilities have positive relation on gross fixed capital formation. Also the result revealed that Total deposit liabilities has significant effect on the economy given the value of t-statistic $(6.03135>1.46)$ at two tails. The finding further shows that a unit percent increase in Total deposit liabilities will bring about $75.03 \%$ increase in the GFCF holding all other factors constant.

The coefficient of credit to private sector (Log CPS) is 0.80I233. This shows that credit to private sector has positive effect on Nigeria's economy measured by Log GFCF. The result reveals that credit to private sector has significant effect on the economy given the value of t-statistic (7.24746>1.96) at two tails. The finding further shows that a unit percent increase in credit to private sector would bring about $80.12 \%$ increase in the GFCF holding all other factors constant.

Lastly, the coefficient of Lending rate (LLRN) is 0.604230 . This shows that prime lending rate has positive significant effect of about $60.42 \%$ on the Nigerian economy measured by GFCF during the observed years. This implies that a unit percent increase in prime lending rate will bring about $60.42 \%$ increase in GFCF. The result further shows that tabulated tstatistic (4.I I772>1.96) at two tails.

\subsection{Diagnostic Test}

Table 5: Summary of Diagnostic Test

\begin{tabular}{lcc}
\hline Test & P-Value & Centered VIF \\
\hline VIF & 0.29 & I.I4, I.I9, I.06 \\
\hline Jarque Berg & \\
\hline Source: Output from Eview I0 Student Edition
\end{tabular}

The Variance Inflation Factor was performed to support the validity of the regression results. Since the values I.I4, I.I9 and I.06 are less than 5 as propounded by Kothari (20I4), it was therefore concluded that there were no multicollinearity among the variables of the model. Jarque-Bera test was used to check for the normality of the data. The results show that the study data are normally distributed given the P-value greater than $5 \%$ significance level. 


\section{I0. Conclusion and Recommendation}

Based on the findings, the study concludes as follows:

Firstly, the study has provided evidence on the three independent variables; credit to private sector, Lending rate and total deposit liabilities in explaining and predicting gross fixed capital formation in Nigeria. The study concluded that the three variables have played a significant role in influencing on Nigeria's gross fixed capital formation. Secondly, the study also establishes significant positive relationship between Lending rate and gross fixed capital formation. It therefore concluded that as lending rate is raised, this in turn increases in the value of gross fixed capital formation. Thirdly, the study documents that credit to private sector has no direct relationship with gross fixed capital formation. This suggests that commercial banks should redirect their intermediation activities effectively.

\section{References}

Arikpo, O. F., \&Adebisi, A. W. (2017). Deposit Money Banking Financing and Its Effect on Real Sector Output in Nigeria: Evidence from Trade and Agricultural Sectors. Advances in Social Sciences Research Journal, 4(I4).

Ajayi, D. D. (2007). Determinants of the volume of production subcontracting in Nigeria. The Nigerian Journal of Economic and Social Studies, 42(I), 95-III.

Aryeetey, E., Baah-Nuakoh, A., Duggleby, T., Hettige, H., \& Steel, W. F. (I994). Supply and demand for finance of small enterprises in Ghana. The World Bank.

Atlaw, A. (20II), The structure, Magnitude and Trends of Capital Formation in and for Agriculture in Ethiopia.

Bakare, A. S. (20II). A theoretical analysis of capital formation and growth in Nigeria. Far East Journal of Psychology and Business, 3(2), I I-24.

Beddies, M. C. H. (1999). Investment, Capital Accumulation, and Growth: Some Evidence From the Gambia I964-I9+ LI65298 (No. 99-II7). International Monetary Fund.

Central Bank of Nigeria (Various issues). Annual report and financial statements. Abuja: Central Bank of Nigeria. Central Bank of Nigeria, 2006. CBN Statistical Bulletin 2006 Edition, Volume I7.

Chin, A. W., Huelga, S. F., \&Plenio, M. B. (2012). Quantum metrology in non-Markovian environments. Physical review letters, $\mathrm{I09}(23), 233601$.

Chukwunonso, S.,Ogonna, E., Clement, I., \& Anthony, O. (2016). Analysis of savings and private capital formation in Nigeria. Research on humanities and social sciences, 6(I2), 2224-5766.

Elser, L. (1999). Strict Dollarization and Economic Performance: An Empirical Investigation. Journal of Money, Credit \& Banking, Eschborn, Washington DC

Ghura, M. D. (1997). Private investment and endogenous growth: Evidence from Cameroon (No. 97-I65). International Monetary Fund.

Gujarati, D. N. (2009). Basic econometrics. Tata McGraw-Hill Education.

Henry, W., Lucky, A., \& Anyamaobi, C. (2016). Banking sector development and capital formation in Nigeria: A multivariate Analysis. Account and financial management journal, I(3) I4I-I6I.

Herald.,\& Heiko. (2009). deposit interest as one of the determining factor for commercial banks

deposits. http://www.cbe.com.et background of Commercial Bank of Ethiopia.

Jhingan M. L. (200I), Money, Banking, International Trade and Public Finance.( $6^{\text {th }}$ Revised and Enlarged Edition).Vrinda Publications (P) Ltd, Delhi, India.

John A, Isaac D and Nathaniel A (2017) Credit risk, deposit mobilization and profitability of Ghanaian banks. International of economics and financial Issues 2017, 7, (5), 394-399

Kazi, A. M. (2012). Promoting deposit mobilization and financial inclusion. Journal of Marketing, 5.

Keynes, J. M. (1964): „,The General Theory of Employment, Interest and Money ${ }^{\text {ee }}$

Laurenceson, J. (2004). Banking industry liberalization, franchise values and deposits mobilization: evidence from international panel data. In International Conference on Industrial Economics and Regulation: Theory and Policy

Mamo, E.A, (2017). An investigation of determinants of deposit mobilization in commercial banks of Ethopia. Research on humanities and social sciences

Mahindra (2005) states that, the number of deposit accounts is more important.

Mohammad and Mahdi, (2010), capital market forces balance interest rates.

Mohammad Namazi and Mahdi Salehi(2010). The Role of Inflation in Financial Repression: Evidence from Iran. IDOSI Publications, World Applied Sciences Journal I I(6): 653-66I.

Mohan, S. (2012). Perspectives of Deposit Mobilisation. online publication.

Nwaeze,et.al (20I I) Financial intermediation and economic growth and capital formation in developing nation (I992 - $201 \mathrm{I}$ ) banking and finance department, Abia state polytechnic, Nigeria.I9,20I7.

Nzotta, S. M. (2004). Money, banking and finance: Theory and practice. Owerri: Hudson-Jude Nigeria Publishers. 
Ogar, A. \& Oba, F. (2017). Impact of financial deepening on capital formation in Nigeria. International journal of research in management \& social sciences, 5(II), 2322-0899.

Ogar, A., \& Gabriel, E. E. (20I5). The contribution of deposit money banks on the growth of the agricultural sector in Nigeria. Archives of Business Research, 3(2).

Ojong, C. M., Arikpo, O. F., \& Anthony, O. (2015). The role of deposit money banks on the growth of smes in yakurr local government area, cross river state, nigeria. Journal of Social Science Research, 6(2), I047-I054.

Orji, A. (2012). Bank Savings and Bank Credits in Nigeria: Determinants and Impact on Economic. International Journal of Economics and Financial Issues, 2(3), 357-372.

Opoku, S. (20I I). Mobilizing deposits; the role of commercial banks in Ghana. Doctoral dissertation.

Omankhanlen, A. E. (2012). The role of banks in capital formation and economic growth: The case of Nigeria. Economy Transdisciplinarity Cognition, I5(I), I03-I I I.

Paschal, O, Chibueze, A.,\& Callistus, O. (2016). Bank credit and capital formation in Nigeria. Journal of policy and development studies IO(2), I57-9385.

Philip, J. (1968).states that the offering of attractive interest rate on bank deposits may be considered to have had a beneficial effect.

Patrick, H. T. (1966). Financial development and economic growth in underdeveloped countries. Economic development and Cultural change, I4(2), I74-I89.

Richard, T., Florence, M., \& Zenon, M. (2015). The effects of deposits mobilization of financial performance in C.BS in Rwanda. A case of Equity bank Rwanda limited. International Journal of Small Business and Entrepreneurship Research, 3(6), 44-7I.

Shettar, M., \& Rajeshwari, D. (20I4). Deposit Mobilization and Socio-Economic Impact: A Case Study of Union Bank Of India. IOSR Joumal of Engineering, 4(5), 2I-26.

Shuaib, I. M., \& Ndidi, N. D. E. (2015). Capital formation: impact on the economic development of Nigeria I9602013. European Journal of Business, Economics and Accountancy, 3(3), 23-40.

Schmidt-Hebbel, K. (1999). The economics of saving and growth. Cambridge University Press.

Tafirei, M., Rabson, M., Linda, C., \& Gumbo. (20I4). Analyzing the relationship between Banks' Deposit Interest Rate and Deposit mobilization: Empirical evidence from

Zimbabwean Commercial Banks Journal of Business And Management 2(16), 64-75.

Uremadu, S. O. (2002). Introduction to finance. Benin: Mindex Publishing Company Ltd.

Uremadu, S. O. (2006). The impact of real interest rate on savings Mobilization in Nigeriat. An unpublished Ph. D Thesis proposal submitted to the Department of Banking and finance, UNN, Enugu Campus.

Ugwuegbe, S. U., \& Uruakpa, P., C. (20I3). The Impact of Capital Formation on the Growth

of Nigerian Economy. Research Journal of Finance and Accounting, 4(9), 36-40.

Venkati P (2016) Impact of banks deposit mobilization and credit financing in capital formation. International research journal of marketing and economics. .3(6), 2349-03I4.

\section{Copyrights}

Copyright for this article is retained by the author(s), with first publication rights granted to the journal. This is an open-access article distributed under the terms and conditions of the Creative Commons Attribution license (http://creativecommons.org/licenses/by/4.0/). 